\title{
Identification of Some Carnivore Animals By Pcr Technique
}

\author{
A. M. Salankar ${ }^{1}$, S. B. Chaudhari ${ }^{2}$, P.M. Gedam ${ }^{3}$, S.B. Banubakode ${ }^{4}$, R.S. \\ Dalvi $^{5}$, N. V. Kurkure ${ }^{6}$. \\ 1, 3, 4, 5- department of veterinary anatomy, NVC Nagpur, India \\ 2- Department of veterinary extension. 6- deptt. of veterinary pathology NVC Nagpur, India
}

\begin{abstract}
In order to protect the endangered wild animal species, to maintain the biodiversity, controls the poaching and finally to lock up the criminals behind bars, it is necessary to develop accurate and authentic methods for identification of wild animals. The present work has been undertaken to verify the utility of species specific primer for identification of various species of carnivore animals. The DNA from blood samples of tiger, leopard, wolf and jackal were isolated by alcohol-chloroform method and subjected to PCR assay using species specific primers. The results of the present study indicated that the species specific primer would be useful in identification of carnivore animal species.
\end{abstract}

Keywords: carnivore, DNA, PCR, primer sequence.

\section{Introduction}

The wildlife population in India has declined heavily through the combination of habitat loss and extreme poaching. There are ever increasing incidences of crime against wild animals by poachers. Many wild animal species are being declared as endangered species.

Species differentiation by use of DNA fingerprinting is becoming very popular in wild life forensic cases. Kocher et al. (1995) have shown that some highly conserved regions on the mitochondrial (mt) cythochrome $b$ gene are suitable for species identification in vertebrates. The PCR technique is quite reliable, accurate, and authentic but requires species-specific or conserved oligonucleotide primers for identification of species.

The preservation of wild animal has become very essential to maintain the biodiversity. Although many efforts are being made at different levels for protecting the life of these wild animals, they often fall pray at the hands of human beings, who are involved in crimes including poaching. After crime has committed, some biological material remains behind as evidence, which can prove to be conspicuous enough to lock up the criminals.

\section{Materials and methods}

For the present work blood samples of Leopard, Wolf and Jackal were collected from Maharaj Bagh Zoo, Nagpur, while the blood sample from Tiger was collected from naturally died tiger during postmortem performed at Government Polyclinic, Chandrapur. The blood samples were collected in sterile $15 \mathrm{ml}$ polypropylene tube containing $0.5 \mathrm{ml}$ of $0.5 \mathrm{M}$ Ethylene Diamine Tetra Acetate (EDTA) solution. After collection, samples were kept at $-20^{\circ} \mathrm{C}$ till further processing.

Isolation of DNA:- DNA from tissue samples was isolated by standard methods of Proteinase $\mathrm{K}$ digestion, phenol-chloroform extraction, and DNA precipitation in ethanol (Sambrook and Russel, 2001). The samples were thawed and transferred to $15 \mathrm{ml}$ polypropylene centrifuge tube and centrifuged at $3000 \mathrm{rpm}$ for 20 $\mathrm{min}$. The reddish tinged supernatants were discarded, then centrifuge at the rate $3000 \mathrm{rpm}$ for $15 \mathrm{~min}$ by mixing chilled RBC lysis buffer incubated with rotation for $12-24 \mathrm{hrs}$ at $50^{\circ} \mathrm{C}$. Equal amount of extraction buffer was added (0.01M NaCl, 0.01M Tris-HCL, 0.1M EDTA (pH 8.0), $1 \mathrm{mg} / \mathrm{mL}$ Proteinase K and $1 \%$ SDS), Similar extraction was done once with phenol:chloroform:isoamyl alcohol (25:24:1) and once with chloroform:isoamyl alcohol (24:1). The precipitated DNA was transferred into a sterile $1.5 \mathrm{ml}$ eppendorf tube (using the wide bore micro tip of $1 \mathrm{ml}$ capacity) and centrifuged @ 10,000 rpm for $10 \mathrm{~min}$ in microcentrifuge at room temperature. The DNA pellet was then washed twice with 70\% ethanol. After $2 \mathrm{hrs}$ incubation, the DNA was cooled and stored at $-20^{\circ} \mathrm{C}$ for further use.

\section{1) Quality check and quantization of DNA}

The quality and purity of DNA were checked and quantization done by UV spectrophotometry and agarose gel electrophoresis. The DNA samples were diluted 1:50 by dissolving $20 \mu \mathrm{l}$ of DNA in $980 \mu \mathrm{l}$ autoclaved distilled water and used for spectrophotometry, DNA samples with an OD260:280 ratio of 1.8 to 2.0 were further subjected to agarose gel electrophoresis for quality check. Electrophoresis was carried out using 0.8 percent agarose in $0.5 \mathrm{X}$ TBE $(\mathrm{pH}$ 8.0) buffer. Agarose in $0.5 \mathrm{X}$ TBE buffer was boiled in microwave oven for 5 
minutes and allowed to cool. Ethidium bromide (1\%) was added at the rate of $5 \mu \mathrm{l} / 100 \mathrm{ml}$ of agarose gel solution. The wells were carefully charged with $5.0 \mu \mathrm{l}$ DNA mixed with $1.0 \mu \mathrm{l} 6 \mathrm{X}$ gel loading dye. Electrophoresis was carried out at $80 \mathrm{~V}$ for 20-30 minutes at room temperature. The gel was visualized under UV transilluminator. The DNA concentration was determined and samples were diluted upto the final concentration of $30 \mathrm{ng} / \mu \mathrm{l}$ with MiliQ water and stored at $-20^{\circ} \mathrm{C}$. DNA was used @ 1-3 $\mu \mathrm{l}$ template for PCR reaction.

\section{2) Primer sequence}

The primer sequences were derived from the gene bank by using primer BLAST. The sequences used to identify species of animals are as follows.

Table 1

\begin{tabular}{|c|c|}
\hline SPECIES & PRIMER SEQUENCE \\
\hline Tiger (Forward) & 5'GCTCACTACCCCTCCTAGTCGC 3' \\
\hline Tiger (Reverse) & 5' AGCCGGCAATGGGAGCTTCG 3' \\
\hline Leopard (Forward) & 5' TCCCCGCTCTCCACACTTCCA 3' \\
\hline Leopard (Reverse) & 5' GCCACCAATTCACGTCAGGGCT 3' \\
\hline Wolf (Forward) & 5' TCTTCTCGCTCCGGGCCCAT 3' \\
\hline Wolf (Reverse) & 5' TGCCGTTGCGGTCGTAGGTG 3' \\
\hline Jackal (Forward) & 5' CAATCCAACATCTCAGCATACC 3' \\
\hline Jackal (Reverse) & 5' CCTGATCAGAATGATATTT ATG 3' \\
\hline
\end{tabular}

\section{3) PCR Reaction}

PCR was carried out in a final reaction volume of $25 \mu$ l. Each reaction volume contained 10X PCR buffer (with $\mathrm{MgCl} 2) 2.50 \mu \mathrm{l}$, dNTPs $(10 \mathrm{mM}$ each) $1.50 \mu \mathrm{l}$, Primer mix (10 pmole $/ \mu \mathrm{l}) 2.00 \mu \mathrm{l}$, Taq DNA polymerase $(5 \mathrm{U} / \mu \mathrm{l}) 1.50 \mu \mathrm{l}$, DNA Template $5.00 \mu \mathrm{l}$, DNase free water $11 \mu \mathrm{l}$

\section{4) PCR protocol}

Initial denaturation $95^{\circ} \mathrm{C} 10 \mathrm{~min}$, denaturation $95^{\circ} \mathrm{C} 30 \mathrm{sec}$, annealing $60^{\circ} \mathrm{C} 30 \mathrm{sec}$, extension $72^{\circ} \mathrm{C} 30$ sec and final extension $72^{\circ} \mathrm{C} 10$ min with 35 cycles. For tiger and leopard annealing temperature was $60^{\circ} \mathrm{C}$, for wolf annealing was $58^{\circ} \mathrm{C}$ and for jackal annealing was $57^{\circ} \mathrm{C}$.For loading the sample, $5 \mu$ diluted DNA was taken and after mixing it with $2 \mu \mathrm{l}$ of $6 \mathrm{X}$ gel loading dye in the electrophoresis tank containing $1 \mathrm{X}$ TBE buffer. A DNA marker was also run in one of the well. Electrophoresis was performed at $80 \mathrm{~V}$ for $80-90 \mathrm{~min}$. After electrophoresis, the gel was visualized under UV transilluminator and documented by gel documentation system. Finally, the PCR product was kept at $-20^{\circ} \mathrm{C}$ for further use.

\section{Result and discussion}

The present study was conducted for identification of carnivore species such as tiger, leopard, wolf and jackal from blood samples by using mtDNA PCR technique. The blood samples collected from these species of animals were subjected for isolation of mitochondrial DNA as follows.

Isolation of mitochondrial DNA:-

Extraction of good quality (high molecular weight) DNA is the prime requirement for success of molecular research especially for genetic aspects. The DNA samples with OD ratio (260/280) 1.7 to 2.0 were included in the experiment. Further, the DNA samples were electrophoresed on $0.8 \%$ agarose gel. The DNA yield ranged from $100 \mu \mathrm{g}$ to $400 \mu \mathrm{g}$ from $1 \mathrm{ml}$ of blood samples.

Amplification of mitochondrial DNA by PCR:- Reactions were carried out in a final volume of $25 \mu 1$ containing 90-100 ng of DNA at $2.5 \mathrm{mM} \mathrm{MgCl} 2$ concentration. The PCR was intended to amplify gene fragment of different size in different species by designing a species-specific forward and reverse primer. Initially, species

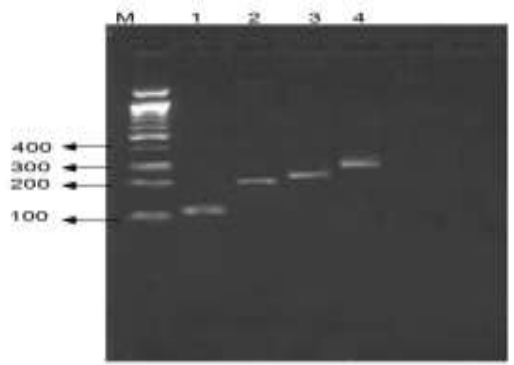

Fig.1. showing various band patterns 
Lane M :- 100bp + 1.5 kb DNA ladder

Lane 1 :- 110bp Leopard

Lane 2 :- $217 \mathrm{bp}$ Tiger

Lane 3 :- 243bp Wolf

Lane 4 :- 325bp Jackal

Specificity of these primers was tested by running a conventional PCR using a pair of primers, (the forward and the reverse primers). Such four PCRs one for each species was formulated and run on respective four species DNA. All the PCRs prominently amplified the target sequences. There was no cross species amplification in any of the reaction i.e. tiger specific PCR gave amplified product only in tiger DNA and not in any of the other DNA.

For each of the PCR, amplicon of expected size was obtained, which was confirmed by running a parallel marker of $100 \mathrm{bp}$. The PCR products were loaded by $5 \mu \mathrm{l}$ per well on $8 \%$ agarose gel and electrophoresed at $80 \mathrm{~V}$ for 60 min using $0.5 \mathrm{X}$ TBE buffer. The electrophorectic band pattern obtained is shown in Figure. The specific PCR amplified fragments to each species produced a characteristic band pattern on agarose gel electrophoresis.

Amplified PCR products from four species were found to range from 110 to $345 \mathrm{bp}$. During the present work, it was noted that the band pattern for tiger, leopard, wolf and jackal was produced at 217, 110, 278 and 310 bp respectively (Fig. 1). These band patterns thus obtained at various base pairs in various species of carnivore animals, indicated a clear-cut demarcation between tiger, leopard, wolf and jackal.

The observations recorded during the present work regarding PCR reaction for species specific primers for tiger is in agreement with the findings recorded by Zhang and Shi (2009). They also reported the band pattern for tiger at $217 \mathrm{bp}$. In contrast with the present findings Bhagavatula and singh (2006) reported a band pattern at $636 \mathrm{bp}$ and $759 \mathrm{bp}$ in the Bengal tiger Panthera tigris tigris. This variation in the band pattern may be attributed to the variation in species specific primer sequence used by them.

During the present study, the leopard showed band pattern at $110 \mathrm{bp}$. This observation of the present study is in agreement with the findings reported by Uphyrkina et al. (2001) and Mukherjee et al. (2010). However, Janczewski et al. (1995) who used universal primer for felidae reported variation in band pattern for leopard species at 358 bp and 289 bp for mitochondrial 12S RNA and cytochrome b protein coding gene respectively. Zhang et al. (2006) in contrast with the findings of the present study reported the band pattern at $500 \mathrm{bp}$ and $287 \mathrm{bp}$ in Panthera tigris and Panthera pardus by using universal primer for Panthera species.

The species specific mtDNA primer produced a PCR product at $278 \mathrm{bp}$ for wolf species in the present study. This observation of the present study coincides with the findings reported by Vila et al. (1999). However in contrast with the findings of the present study Pilgrim et al. (1998) reported a band pattern at 440 bp by using the universal primer and at $164 \mathrm{bp}$ by using canid specific primer. This variation in band pattern could be attributed to the difference in the primer sequence.

During the present study, the jackal showed band pattern at 310 bp by using species specific primers. This observation of present study is in agreement with the findings reported by Wayne et al. (1989) in jackal.

\section{Conclusion}

From the present study it is concluded that the species specific primers are useful for identification of species by PCR technique.

\section{References}

[1] Bhagavatula, J. and L. Singh (2006) Genotyping faecal samples of Bengal tiger Panthera tigris tigris for population estimation: A pilot study. BMC Genetics 1471-2156-7-48.

[2] Janczewski, D. N.; W. S. Modi; J. C. Stephens and S. J. O’Brien (1995) molecular evolution of mitochondrial 12S RNA and cytochrome $b$ sequences in the Pantherine Linease of Felidae, molecular biology of evolution 12(4): 690-707.

[3] Kocher, T.D.; Thomas, W.K.; Meyer, A.M.; Edwards, S.V.; Paabo, S.; Villablanca, F.X. and Wilson, A.C. (1995). Proc. Natl. Acad. Sci. (86): 6196-6200.

[4] Mukherjee, S.; C. N. Ashalakshmi; H. Chandrima and U. Ramakrishnan (2010) An evaluation of the PCR-RFLP technique to aid molecular based monitoring of felids and canida in India. BMC Research Notes 2010, 3: 159.

[5] Pilgrim, K.L.; D. K. Boyd and S. H. Forbes (1998) Testing for wolf-coyote hybridization in the rocky mountain using mitochondrial DNA. Journal of wildlife management 62 (2) 683-689

[6] Sambrook J. and D.W. Russell (2001) Molecular cloning - A laboratory manual. Third edition Cold Spring Harbour Laboratory Press, New York.

[7] Uphyrkina, O.; Warren E. Johnson; Howard Quigley; Dale Miquelle and Laurie Marker (2001) Phylogenetics genome diversity and origin of modern leopard, Panthera pardus. Journal of Molecular Ecology 10: 2617-2633.

[8] Villa, C.; I. R. Amorim; J. A. Leonard; D. Castroviejo and F. Pecrucci-Fonseca (1999) Mitochondrial DNA phylogeography and population history of grey wolf Canis lupus. Journal of molecular ecology 8:2089-2103.

[9] Wayne, K. K.; A. Mayer; N. Lahman; B. Valkenburgh; P. W. Kat; T.K. Fuller and D. Girman (1989) large sequence divergence among mitochondrial DNA genotypes within population of eastern African black -backed jackals. Proc. Natl. Acad. Sci. USA 87:1772-1776.

[10] Zhang, W.; Z. Zhang; F. Shen; R. Hou; L .V. Xiaoping and B. Yue (2006) Highly conserved D-loop-like nuclear mitochondrial sequences (Numts) in tiger (Panthera tigris). Journal of Genetics, 85(2):106-109.

[11] Zhang, S. Q. and J. S. Shi (2009) phylogenetic relationship of Panthera tigris amoyensis, Panthera tigris altaica and Panthera tigris tigris based on mitochondrial DNA sequences. Gene bank. Accession No. FJ694971. 